\title{
Potential impacts of clearcutting on parasites of minnows in small boreal lakes
}

\author{
David J. Marcogliese ${ }^{1}$, Mark Ball ${ }^{2}$ and Murray W. Lankester ${ }^{3}$
}

${ }^{1}$ St. Lawrence Centre, Environment Canada, 105 McGill, $7^{\text {th }}$ Floor, Montreal, Quebec, H2Y 2E7, Canada;

${ }^{2}$ Department of Fisheries and Oceans, Gulf Fisheries Centre, Moncton, New Brunswick, E1C 9B6, Canada;

${ }^{3}$ Department of Biology, Lakehead University, Thunder Bay, Ontario, P7B 5E1, Canada

Key words: parasites, clearcutting, northern redbelly dace, Phoxinus eos

\begin{abstract}
Clearcutting and deforestation lead to increased erosion, increased water temperature, altered water chemistry, and modified watershed hydrology in aquatic systems. Effects on biological organisms have been documented for phytoplankton, zooplankton, benthos, and fish. In this study, parasites of the northern redbelly dace, Phoxinus eos (Cope), were examined from an experimental area consisting of headwater lakes and their watersheds in the boreal forest of Ontario, Canada prior to and after clearcutting around the lakes. Catchments of two lakes were heavily, and one lake partially, clearcut in 1996, and that of a fourth lake was untouched. In 1993, three years prior to clearcutting, five taxa of parasites, including the monogeneans Dactylogyrus sp. and Gyrodactylus sp., metacercaria of the digenean Clinostomum complanatum (Rudolphi, 1819), the nematode Rhabdochona canadensis Moravec et Arai, 1971 and the myxozoan Myxobolus sp. were found in or on northern redbelly dace. In 1998, two years after clearcutting, eight taxa were found on northern redbelly dace, including all of the above plus the digeneans Allocreadium sp. and Ornithodiplostomum ptychocheilus (Faust, 1917) and the copepod Ergasilus lizae Krøyer, 1863. Mean infracommunity species richness and the maximum number of species per fish were higher in the control and partially cut lake than in the heavily logged lakes. Uninfected fish were found in the heavily cut lakes, but not in the other lakes. Thus, disturbance may reduce parasite infracommunity complexity. Among individual parasite species, $R$. canadensis was absent from the two most heavily clearcut lakes and abundant in the two other lakes in 1998. Clearcutting may have affected the abundance of certain invertebrates in these lakes, in particular the mayflies that serve as intermediate hosts for $R$. canadensis. The parasites Allocreadium sp., O. ptychocheilus, and E. lizae have not been previously reported in or on northern redbelly dace.
\end{abstract}

The detrimental effects of clearcutting and deforestation on streams are well documented. They include increased erosion, increased water temperature, altered water chemistry, and modified watershed hydrology, with subsequent consequences for their biota (Freedman 1995). Presumably, effects of clearcutting and deforestation on lakes are similar, but may be delayed or diminished by dilution of runoff in the greater volumes of water in lakes compared to streams (Carignan and Steedman 2000).

For small boreal lakes, clearcutting has been shown to affect runoff, mixing, and nutrient dynamics (Rask et al. 1993, Carignan et al. 2000, Lamontagne et al. 2000, Scully et al. 2000, Steedman 2000, Steedman and Kushneriuk 2000). Consequences of clearcutting for the biota include increased primary production and changes in the communities of phytoplankton, benthic insects, and zooplankton (Rask et al. 1993, Burton and Ulrich 1994, Patoine et al. 2000), with more subtle alterations in fish communities (St-Onge and Magnan 2000). Given that alterations may occur to food webs in lakes, it is expected that corresponding changes will occur in parasite communities of fish, as parasites are often dependent on trophic interactions for transmission
(Marcogliese and Cone 1997). Although, to our knowledge, no study to date has examined the effects of clearcutting on the parasite fauna of aquatic systems, deforestation has affected the occurrence of human parasitic diseases in various parts of the world through effects on vectors and reservoir hosts in aquatic environments (Walsh et al. 1993).

In this study, parasites of a common small cyprinid fish were examined from a series of experimental lakes as part of a multidisciplinary field program designed to determine the effects of clearcut logging on abiotic and biotic parameters in small boreal lakes.

\section{MATERIALS AND METHODS}

Study lakes are located in the Ontario Ministry of Natural Resources' (OMNR) Coldwater Lakes Experimental Watersheds (CLEW) in the transition zone between boreal and Great Lakes forests on the Canadian Shield, approximately $200 \mathrm{~km}$ northwest of Thunder Bay, Ontario, Canada. Detailed limnological and climatological descriptions of the study sites are provided in Steedman (2000) and Steedman and Kushneriuk (2000). Four study lakes were sampled, including

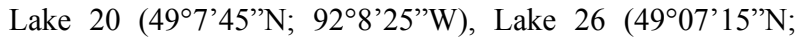
$\left.92^{\circ} 08^{\prime} 45^{\prime \prime} \mathrm{W}\right)$, Lake $39\left(49^{\circ} 05^{\prime} 30^{\prime \prime} \mathrm{N}\right.$; $\left.92^{\circ} 10^{\prime} 00^{\prime \prime} \mathrm{W}\right)$, and Lake 
$42\left(49^{\circ} 05^{\prime} 00^{\prime \prime} \mathrm{N} ; 92^{\circ} 09^{\prime} 30^{\prime \prime} \mathrm{W}\right)$. All lakes are between 26 and 57 ha in surface area and 18 and $37 \mathrm{~m}$ mean depth. As part of a multidisciplinary field experiment administered by the OMNR's Centre for Northern Ecosystem Research (CNFER) to evaluate effects of forestry practices on lakes, catchments of three lakes (Lake 26, Lake 39, and Lake 42) were harvested by commercial loggers in 1996. The areas around Lakes 39 and 42 were extensively deforested $(60-70 \%)$, with only 40 to $60 \%$ of the shoreline left untouched as controlled buffer zones. Lake 26 had no shoreline disturbance, and only a moderate amount $(33 \%)$ of catchment deforestation. The catchment around Lake 20 was left in an uncut state.

Baited minnow traps $\left(0.5 \mathrm{~cm}^{2}\right.$ mesh $)$ were placed at random in each lake at depths of 1 and $3 \mathrm{~m}$ and left for 24 hours in July and August 1998. Care was taken not to place traps in the vicinity of controlled buffer zones on lakes 42 and 39. Northern redbelly dace, Phoxinus eos (Cope), were collected, stored individually in labelled freezer bags, and frozen until necropsy. Fish samples prior to clearcutting were taken in baited minnow traps deployed for 24 hours by the OMNR in July of 1993 and fixed in 10\% formalin. Effort was made to use preserved samples obtained from the same or nearby sites as those in 1998. Unfortunately, many fish collected in 1993 were improperly fixed. Therefore actual worm counts may be underestimated due to degeneration or loss of worms and are thus considered unreliable. However, the collections are considered to provide a reliable indication of the presence or absence of parasite species in the different samples. Collection data are summarised in Table 1.

Upon examination, each fish was thawed, weighed and measured (fork length). The specimen bag was washed into a Petri dish and the fluid was examined for parasites that may have been dislodged during storage. Minnows fixed in $10 \%$ formalin were soaked in water to remove the fixative before examination. The water bath was also examined for parasites. The external surface, fins, eyes, gills, body cavity, stomach, intestine, liver, gall bladder, kidney, heart, gonad, urinary bladder and swim bladder were examined using a stereomicroscope at 16-24×. Wet mounts made from smears of each organ onto a slide were examined for microparasites under a compound microscope at $400 \times$. Nematodes were heat relaxed in warm (not boiling) 70\% ethanol. All parasites found were stored in glass vials containing $10 \%$ glycerine in $70 \%$ ethanol.

Platyhelminths and arthropods were prepared according to Humason (1972). Nematodes in glycerine-alcohol were placed in partially covered watch glasses. The fixative was allowed to evaporate slowly until specimens in pure glycerine were mounted in Canada balsam. Parasites were identified using Beverly-Burton (1984), Kabata (1988), Mitchum (1995), and Gibson (1996).

Prevalence is defined as the percentage of fish in a sample infected with a given parasite. Mean abundance is the mean number of parasites of a particular taxon per host, including uninfected fish (Bush et al. 1997). Because parasite data did not conform to the assumptions of parametric tests, the mean abundance of the various parasite species collected in 1998 was compared among lakes using a nonparametric one-way analysis of variance (Kruskall-Wallis test).

\section{RESULTS}

Five taxa of parasites were found infecting redbelly dace in 1993. These included two monogeneans, Dactylogyrus sp. on the gills, Gyrodactylus sp. on the gills and skin; one digenean Clinostomum complanatum (Rudolphi, 1819) under the skin; one nematode Rhabdo-chona canadensis Moravec et Arai, 1971 in the intes-tine; and one myxozoan Myxobolus sp. in the kidney (Table 2). In 1998, eight taxa were found in northern redbelly dace, including the two monogeneans; three digeneans, C. complanatum, Allocreadium sp. in the intestine, and Ornithodiplostomum ptychocheilus (Faust, 1917) on the viscera; the nematode $R$. canadensis; the myxozoan Myxobolus sp.; and the copepod Ergasilus lizae Krøyer, 1863 on the gills (Table 2).

Taxon richness varied from one to four in 1993, and from four to six in 1998 (Table 2). Mean species richness per fish was highest (2.1) in the control lake and least $(\leq 1.6)$ in the extensively logged lakes (Table 3 ). An examination of the frequency distribution of the number of parasite taxa per fish in each lake shows that species richness per fish never exceeded three in the extensively cut lakes. Furthermore, uninfected fish were only found in these lakes (Fig. 1). Mean number of parasites per fish varied from 3.9 to 6.1 (Table 3).

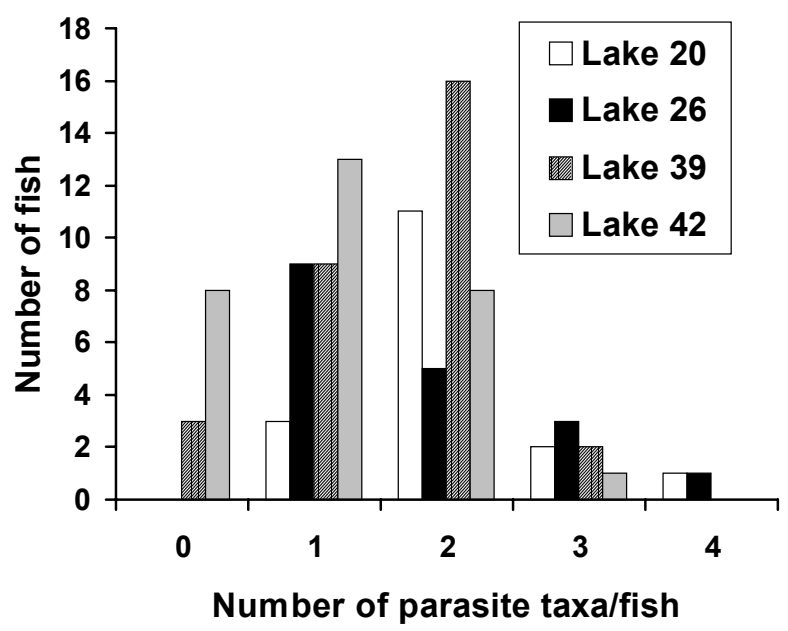

Fig. 1. Frequency distribution of the number of parasite taxa infecting the northern redbelly dace (Phoxinus eos) from Coldwater Lakes, Ontario, Canada, in 1998, two years after clearcutting experimental forest catchment manipulations. Trees around Lakes 39 and 42 were clearcut down to lake margins. Lake 26 was only partially cut, with a buffer zone between the lake and the cutting. Lake 20 was an uncut control.

There were no consistent changes or patterns in the prevalence of parasites in lakes between 1993 and 1998. Dactylogyrus sp. and Gyrodactylus sp. were common $(50-77 \%)$ in northern redbelly dace from Lakes 39 and 42 in 1993, with the former occurring only rarely (4\%) 
Table 1. Summary of sampling information for collections of redbelly dace (Phoxinus eos) from Coldwater Lakes, Ontario, Canada, before (1993) and two years after (1998) clearcutting. Experimental forest catchments were harvested in 1996. Trees around Lakes 39 and 42 were clearcut down to lake margins. Lake 26 was only partially cut, with a buffer zone between the lake and the cutting. Lake 20 was an uncut control.

\begin{tabular}{|l|cc|cc|cc|cc|}
\hline Lake & \multicolumn{2}{|c|}{ Lake 20 } & \multicolumn{2}{c|}{ Lake 26 } & \multicolumn{2}{c|}{ Lake 39 } & \multicolumn{2}{c|}{ Lake 42 } \\
\hline Year & 1993 & 1998 & 1993 & 1998 & 1993 & 1998 & 1993 & 1998 \\
$\mathrm{~N}$ & 25 & 17 & 24 & 18 & 30 & 30 & 30 & 30 \\
Mean length (mm) (土 S.D.) & $51 \pm 2.8$ & $52 \pm 2.0$ & $52 \pm 2.9$ & $53 \pm 2.2$ & $48 \pm 8.4$ & $50 \pm 2.3$ & $51 \pm 2.3$ & $51 \pm 2.1$ \\
\hline
\end{tabular}

Table 2. Prevalence (\%) of various parasite taxa in redbelly dace (Phoxinus eos) from Coldwater Lakes, Ontario, Canada, before (1993) and two years after (1998) clearcutting. Experimental forest catchments were harvested in 1996. Trees around Lakes 39 and 42 were clearcut down to lake margins. Lake 26 was only partially cut, with a buffer zone between the lake and the cutting. Lake 20 was an uncut control.

\begin{tabular}{|l|cc|cc|cc|cc|}
\hline Lake & \multicolumn{2}{|c|}{ Lake 20 } & \multicolumn{2}{c|}{ Lake 26 } & \multicolumn{2}{c|}{ Lake 39 } & \multicolumn{2}{c|}{ Lake 42 } \\
Year & 1993 & 1998 & 1993 & 1998 & 1993 & 1998 & 1993 & 1998 \\
Parasite taxa & & & & & & & & \\
\hline Dactylogyrus sp. & 4 & 35 & 0 & 0 & 50 & 67 & 77 & 73 \\
Gyrodactylus sp. & 0 & 24 & 0 & 61 & 57 & 40 & 70 & 10 \\
Allocreadium sp. & 0 & 18 & 0 & 22 & 0 & 3 & 0 & 10 \\
Clinostomum complanatum & 8 & 0 & 0 & 6 & 0 & 40 & 0 & 0 \\
Ornithodiplostomum ptychocheilus & 0 & 47 & 0 & 11 & 0 & 0 & 0 & 0 \\
Rhabdochona canadensis & 32 & 82 & 4 & 78 & 3 & 0 & 0 & 0 \\
Ergasilus lizae & 0 & 0 & 0 & 0 & 0 & 7 & 0 & 23 \\
Myxobolus sp. & 16 & 6 & 0 & 0 & 0 & 0 & 0 & 0 \\
\hline Number of taxa & 4 & 6 & 1 & 5 & 3 & 5 & 2 & 4 \\
\hline
\end{tabular}

Table 3. Mean abundance ( \pm S.D.) of various parasite taxa in redbelly dace (Phoxinus eos) from Coldwater Lakes, Ontario, Canada, two years after (1998) clearcutting. Experimental forest catchments were harvested in 1996. Trees around Lakes 39 and 42 were clearcut down to lake margins. Lake 26 was only partially cut, with a buffer zone between the lake and the cutting. Lake 20 was an uncut control.

\begin{tabular}{|c|c|c|c|c|}
\hline Parasite taxa & Lake 20 & Lake 26 & Lake 39 & Lake 42 \\
\hline Dactylogyrus sp. & $1.3 \pm 2.0$ & 0 & $3.5 \pm 3.7$ & $4.5 \pm 6.3$ \\
\hline Gyrodactylus sp. & $0.5 \pm 1.0$ & $1.1 \pm 1.3$ & $0.7 \pm 1.1$ & $0.2 \pm 0.5$ \\
\hline Allocreadium sp. & $0.2 \pm 0.6$ & $0.4 \pm 0.9$ & $0.03 \pm 0.2$ & $0.1 \pm 0.3$ \\
\hline Clinostomum complanatum & 0 & $0.1 \pm 0.2$ & $1.1 \pm 2.4$ & 0 \\
\hline Ornithodiplostomum ptychocheilus & $1.6 \pm 1.9$ & $0.3 \pm 1.0$ & 0 & 0 \\
\hline Rhabdochona canadensis & $2.7 \pm 3.5$ & $1.9 \pm 2.1$ & 0 & 0 \\
\hline Ergasilus lizae & 0 & 0 & $0.1 \pm 0.4$ & $0.3 \pm 0.6$ \\
\hline Mean number of parasite taxa per fish ( \pm S.D.) & $2.1 \pm 0.7$ & $1.8 \pm 0.9$ & $1.6 \pm 0.8$ & $1.1 \pm 0.8$ \\
\hline Mean number of parasites ${ }^{1}$ per fish ( \pm S.D.) & $6.1 \pm 4.9$ & $3.9 \pm 2.9$ & $5.4 \pm 5.1$ & $3.9 \pm 5.1$ \\
\hline
\end{tabular}

${ }^{1}$ Excluding Myxobolus sp.

in Lake 20. In 1998, Gyrodactylus sp. was relatively common (40-61\%) only in fish from Lakes 26 and 39, less common $(24 \%)$ in those from Lake 20 , and rare $(10 \%)$ in those from Lake 42 . Dactylogyrus sp. was common in northern redbelly dace from Lakes 39 and $42(67-73 \%)$, less common (35\%) in those from Lake 20 , and absent from the Lake 26 sample. Metacercariae of $C$. complanatum were found only rarely $(8 \%)$ in fish from Lake 20 in 1993, whereas it 1998 it was relatively common (40\%) in northern redbelly dace from Lake 39 and rare $(6 \%)$ in those from Lake 26. Allocreadium sp. occurred at low prevalence $(3-22 \%)$ in fish from all lakes in 1998, and O. ptychocheilus was found only in fish from Lakes 20 and 26 at $47 \%$ and $11 \%$ prevalence, respectively. The nematode $R$. canadensis was uncommon or rare $(3-32 \%)$ in all lakes except Lake 42 in 1993, yet quite common in Lakes 20 and 26 (78-82\%) in 1998. Myxobolus sp. was only encountered rarely in Lake 20 in 1993 (16\%) and 1998 (6\%). Ergasilus lizae was uncommon or rare (7-23\%) in 1998 in samples from Lakes 39 and 42 (Table 2).

Differences among lakes were noted in mean abundance of certain parasites in 1998 (Table 3). Gyrodactylus sp. was significantly more abundant on northern redbelly dace from Lake 26 than those from Lake 42 (Kruskall-Wallis test, chi-square $=14.005, P<$ 
0.005). Metacercariae of $C$. complanatum in northern redbelly dace from Lake 39 significantly outnumbered those of other lakes (Kruskall-Wallis test, chi-square = $25.936, P \leq 0.0001)$. Those of $O$. ptychocheilus were significantly more abundant in northern redbelly dace from Lake 20 compared to those from other lakes (Kruskall-Wallis test, chi-square $=26.127, P \leq 0.0001$ ). Mean abundance of $R$. canadensis was significantly greater in northern redbelly dace from Lake 20 compared to those from Lake 26 (Kruskall-Wallis test, chi-square $=65.061, P \leq 0.0001$ ). The copepod E. lizae was significantly more abundant on northern redbelly dace from Lake 42 compared to those from other lakes (Kruskall-Wallis test, chi-square $=12.450, P<0.01$ ). Numbers of Dactylogyrus sp. did not differ among northern redbelly dace from the three lakes where it was found (Kruskall-Wallis test). Mean abundance of Allocreadium sp. did not differ among northern redbelly dace from the different lakes (Kruskall-Wallis test, chisquare $=5.0966, P>0.05)$.

\section{DISCUSSION}

Parasite species richness was lower in 1993 compared to 1998 for all lakes. However, fish collected in 1993 were not well preserved, and conceivably parasites were lost as a result. Thus, only qualitative parasite data were used to make comparisons between 1993 and 1998. However, given that we could detect the presence of small, delicate ectoparasites in 1993 fish, we believe the assessment of presence or absence of parasites in the lakes to be correct and the qualitative comparisons to be valid.

There appeared to be subtle differences in species richness between the heavily clearcut lakes and the other lakes. Infracommunity diversity, or the number of parasite taxa per fish, tended to be higher in the control and partially cut lakes compared to the heavily logged lakes. Moreover, the maximum number of parasite taxa per fish was higher in the control and partially logged lake, and all fish examined were infected, unlike the heavily cut lakes. Similar frequency distributions were seen in American eels (Anguilla rostrata) whereby eels from acidified streams had a lower maximum number of parasite species per eel than in those from limed streams (Cone et al. 1993). Disturbed systems under stress may possess less complex infracommunities than unperturbed host-parasite systems.

There were no evident distributional patterns of parasites that could be attributed to clearcutting, with one exception. In 1998 the nematode Rhabdochona canadensis was not found in lakes that were completely clearcut down to the shoreline. Yet, the parasite was common and abundant in the control lake and the lake possessing a buffer zone along its margins. In addition, metacercariae of Ornithodiplostomum ptychocheilus were only found in the latter two lakes in 1998. In contrast, the copepod Ergasilus lizae was found only in the most heavily clearcut lakes.

The absence of $R$. canadensis from the heaviest clearcut lakes is striking, especially given that it was observed in one of those lakes in 1993. Moreover, its high abundance and prevalence in the other two lakes further implies that it should be common, or at least present, throughout. This nematode presumably uses a mayfly (Hexagenia spp.) as its intermediate host (Anderson 1992). Mayflies may have severely declined or been eliminated from the heavily clearcut lakes. Differences in numbers and biomass of other invertebrates including insects have been documented after deforestation (Burton and Ulrich 1994, Patoine et al. 2000). Changes were typically most pronounced in the first post-cut year, declining thereafter. In lotic systems ephemeropterans, unlike other invertebrate taxa, showed little signs of recovery for as long as five years after deforestation from natural forest fires (Minshall et al. 1997). In Lake 42, density of chironomids declined in the two years after timber harvesting (Hrabok 1999). Unfortunately, there is no other information on aquatic insects from the CLEW to verify if mayflies were indeed reduced in abundance after clearcutting, and this hy-pothesis should be tested further. Water quality changes were similar among the partially and extensively logged lakes, and no effects that were particular to Lakes 39 and 42 were observed (Steedman 2000). All three har-vested lakes experienced a reduction in water clarity (Steedman and Kushneriuk 2000).

A number of parasites were found in 1998 that were not observed in fish collected in 1993. These included Allocreadium sp., O. ptychocheilus, and E. lizae. These findings may represent colonisation, or alternatively, the parasites were not observed in 1993 as a result of the poor specimen fixation. The latter is unlikely, as small, fragile parasites such as Gyrodactylus sp. were detectable in the 1993 fixed samples. The fact that one parasite (E. lizae) was observed in the heaviest cut lakes, and the other (O. ptychocheilus) in the least cut lakes, may simply reflect chance colonisation events, but it cannot be ruled out that their distributions are in some way affected by deforestation.

Interestingly, Dactylogyrus sp. was most prevalent and abundant in the heavily clearcut lakes. Koskivaara et al. (1991) reported that the intensity of Dactylogyrus spp. was highest in a stressed, polluted system compared to lesser-impacted lakes. In the case of the Coldwater Lakes, the patterns of this parasite's prevalence were similar in 1993 compared to 1998, and the differences may simply reflect its natural distribution.

The parasites Allocreadium sp., O. ptychocheilus, and $E$. lizae have not been reported in or on northern redbelly dace previously, although there are records of 
Neascus sp. in Ontario (Margolis and Arthur 1979, McDonald and Margolis 1995, Hoffman 1999). Two species of Dactylogyrus (D. chrosomi Hanek, Molnár et Fernando, 1975 and D. eos Hanek, Molnár et Fernando, 1975) and one unidentified species of Gyrodactylus have been observed on the gills of northern redbelly dace in Ontario (Margolis and Arthur 1979, McDonald and Margolis 1995). Only one species of Myxobolus (M. conspicuus Kudo, 1929) has been found on northern redbelly dace and that occurred on the skin (McDonald and Margolis 1995). However, a number of other species in the genus have been found in the visceral organs of various cyprinid fish in Ontario. Only one species of Allocreadium, A. lobatum Wallin, 1909 is found in eastern Canada, occurring in cyprinids
(McDonald and Margolis 1995); the only other species found in Canada was in the west. It is likely that the species found on northern redbelly dace is A. lobatum.

Acknowledgements. We thank the Ontario Ministry of Natural Resources' Centre for Northern Forest Ecosystem Research, and Rob Steedman in particular, for providing logistical support, accommodations, and laboratory facilities at the Coldwater Lakes Experimental Watersheds in 1998. We also are grateful to the Ecological Monitoring and Assessment Network, Environment Canada, Burlington, Ontario, for providing financial support for the field component of this study. Stephanie Barbeau is acknowledged for assisting with the analysis, and Drs. Robert Steedman and Jane Cook for commenting on the manuscript.

\section{REFERENCES}

ANDERSON R.C. 1992: Nematode Parasites of Vertebrates: Their Development and Transmission. C.A.B. International, Wallingford, U.K., 578 pp.

BEVERLEY-BURTON M. 1984: Monogenea and Turbellaria. In: L. Margolis and Z. Kabata (Eds.), Guide to the Parasites of Fishes of Canada. Part I. Can. Spec. Publ. Fish. Aquat. Sci. 74: 5-209.

BURTON T.M., ULRICH K.E. 1994: The effects of wholetree harvest on insects associated with leaf packs in small streams in New Hampshire. Verh. Int. Ver. Limnol. 25: 1483-1491.

BUSH A.O., LAFFERTY K.D., LOTZ J.M., SHOSTAK A.W. 1997: Parasitology meets ecology on its own terms: Margolis et al. revisited. J. Parasitol. 83: 575-583.

CARIGNAN R., D'ARCY P., LAMONTAGNE S. 2000: Comparative impacts of fire and forest harvesting on water quality in Boreal Shield lakes. Can. J. Fish. Aquat. Sci. 57 (Suppl. 2): 105-117.

CARIGNAN R., STEEDMAN R.J. 2000: Impacts of major watershed perturbations on aquatic ecosystems. Can. J. Fish. Aquat. Sci. 57 (Suppl. 2): 1-4.

CONE D.K., MARCOGLIESE D.J., WATT W.D. 1993: Metazoan parasite communities of yellow eels (Anguilla rostrata) in acidic and limed rivers of Nova Scotia. Can. J. Zool. 71: 177-184.

FREEDMAN B. 1995: Environmental Ecology. The Ecological Effects of Pollution, Disturbance, and Other Stresses. Second Edition. Academic Press, San Diego, California, $606 \mathrm{pp}$.

GIBSON D.I. 1996: Trematoda. In: L. Margolis and Z. Kabata (Eds.), Guide to the Parasites of Fishes of Canada. Part IV. Can. Spec. Publ. Fish. Aquat. Sci. 124, 373 pp.

HOFFMAN G.L. 1999: Parasites of North American Freshwater Fishes. $2^{\text {nd }}$ Ed. Comstock Publishing Associates, Ithaca, New York, 539 pp.

HRABOK J.T. 1999: The use of aquatic insect emergence (Diptera: Chironomidae) in biological surveillance following experimental riparian deforestation at the Coldwater Lakes Experimental Watersheds northwestern Ontario. M.Sc. Thesis, Lakehead University, Thunder Bay, Ontario, $104 \mathrm{pp}$.
HUMASON G.L. 1972: Animal Tissue Techniques. Third Edition. W.H. Freeman and Company, San Francisco, California, $641 \mathrm{pp}$.

KABATA Z. 1988. Copepoda and Branchiura. In: L. Margolis and Z. Kabata (Eds.), Guide to the Parasites of Fishes of Canada. Part II - Crustacea. Can. Spec. Publ. Fish. Aquat. Sci. 101: 3-127.

KOSKIVAARA M., VALTONEN E.T., PROST M. 1991: Dactylogyrids on the gills of roach in Central Finland: features of infection and species composition. Int. J. Parasitol. 21: 565-572.

LAMONTAGNE S., CARIGNAN R., D'ARCY P., PRAIRIE Y.T., PARÉ D. 2000: Element export in runoff from eastern Canadian Boreal Shield drainage basins following forest harvesting and wildfires. Can. J. Fish. Aquat. Sci. 57 (Suppl. 2): 118-128.

MARCOGLIESE D.J., CONE D.K. 1997: Food webs: a plea for parasites. Trends Ecol. Evol. 12: 320-325.

MARGOLIS L., ARTHUR J.R. 1979: Synopsis of the Parasites of Fishes of Canada. Bull. Fish. Res. Board Can. 199, Ottawa, 269 pp.

McDONALD T.E., MARGOLIS L. 1995: Synopsis of the Parasites of Fishes of Canada: Supplement (1978-1993). Can. Spec. Publ. Fish. Aquat. Sci. 122, Ottawa, 265 pp.

MINSHALL G.W., ROBINSON C.T., LAWRENCE D.E. 1997: Postfire responses of lotic ecosystems in Yellowstone National Park, U.S.A. Can. J. Fish. Aquat. Sci. 54: 2509-2525.

MITCHUM D.L. 1995: Parasites of Fishes in Wyoming. Wyoming Fish and Game Department, Cheyenne, Wyoming, 304 pp.

PATOINE A., PINEL-ALLOUL B., PREPAS E.E., CARIGNAN R. 2000: Do logging and forest fires influence zooplankton biomass in Canadian Boreal Shield lakes? Can. J. Fish. Aquat. Sci. 57 (Suppl. 2): 155-164.

RASK M., ARVOLA L., SALONEN K. 1993: Effects of catchment deforestation and burning on the limnology of a small forest lake in southern Finland. Verh. Int. Ver. Limnol. 25: 525-528.

SCULLY N.M., LEAVITT P.R., CARPENTER S.R. 2000: Century-long effects of forest harvest on the physical 
structure and autotrophic community of a small temperate lake. Can. J. Fish. Aquat. Sci. 57 (Suppl. 2): 50-59.

STEEDMAN R.J. 2000: Effects of experimental clearcut logging on water quality in three small boreal lake trout (Salvelinus namaycush) lakes. Can. J. Fish. Aquat. Sci. 57 (Suppl. 2): 92-96.

STEEDMAN R.J., KUSHNERIUK R.S. 2000: Effects of experimental clearcut logging on thermal stratification, dissolved oxygen, and lake trout (Salvelinus namaycush) habitat volume in three small boreal forest lakes. Can. J. Fish. Aquat. Sci. 57 (Suppl. 2): 82-91.

ST-ONGE I., MAGNAN P. 2000: Impact of logging and natural fires on fish communities of Laurentian Shield lakes. Can. J. Fish. Aquat. Sci. 57 (Suppl. 2): 165-174.

WALSH J.F., MOLYNEUX D.H., BIRLEY M.H. 1993: Deforestation: effects on vector-borne disease. Parasitology 106: S55-S75.

Accepted 16 May 2001 